\title{
PEMBERDAYAAN MASYARAKAT SONAF DAN MANEKA MELALUI KEGIATAN BETERNAK BABI PEDAGING DAN BERCOCOKTANAM JAGUNG
}

\author{
Yosefina Lewar" ${ }^{\# 1}$ Mochammad Hasan*2, Blasius Gharu ${ }^{\# 3}$ \\ \#1Jurusan Tanaman Pangan dan Hortikultura dan Jurusan Manajemen Pertanian Lahan Kering, \\ Politeknik Pertanian Negeri Kupang \\ Jl. Prof. Dr. Herman Yohanes - Lasiana - Kupang - Nusa Tenggara Timur \\ 1email.yosefina.lewar087@gmail.com \\ 3email.gharublasius@yahoo.com \\ ${ }^{*}$ Jurusan Tanaman Pangan dan Hortikultura, Politeknik Pertanian Negeri Kupang \\ Jl. Prof. Dr. Herman Yohanes - Lasiana - Kupang - Nusa Tenggara Timur \\ 2email.mochas@yahoo.co.id
}

\begin{abstract}
ABSTRAK
Mitra kegiatan IbM ini adalah para penghuni sebuah panti asuhan di Kota Kupang yakni Panti Asuhan Sonaf Maneka karena terdiri atas 2 kelompok yaitu Kelompok Sonaf (kaum laki-laki) yang berperan sebagai mitra 1 dan kelompok Maneka (kaum perempuan) berperan sebagai mitra 2. Mitra 1 mengelola ternak babi pedaging sedangkan mitra 2 mengelola tanaman jagung dan pembuatan pupuk kompos dari jerami jagung. Kedua mitra memiliki lahan yang cukup luas $( \pm 20$ are) yang belum dimanfaatkan secara optimal. Kondisi sekarang menunjukan bahwa mitra 1 beternak babi skala kecil (2 ekor babi) dengan teknologi yang sederhana seperti perkandangan tradisional, bibit babi lokal serta pakan seadanya tanpa memperhatikan nilai gizi atau nutrisi. Pakan babi diberikan dari sisasisa limbah dapur dan makanan masyarakat panti asuhan. Sedangkan mitra 2 mengelola lahan dengan menanam beberapa jenis tanaman seperti jagung dan sayuran dalam skala kecil untuk dikonsumsi sendiri. Teknik beternak babi dan budidaya tanaman masih bersifat tradisional/sederhana tersebut berdampak pada rendahnya produktivitas. Produksi ternak babi dapat ditingkatkan apabila menggunakan bibit babi unggul dengan pakan berkualitas dalam sistem perkandangan yang proposional dan sehat. Pakan berkualitas dapat diramu menggunakan bahan lokal seperti jagung. Kegiatan ini dilakukan dengan metode penyuluhan, praktek/demplot, pendampingan, monitoring dan evaluasi. Kegiatan untuk kedua mitra berhasil dengan baik, ditunjukan dengan ternak babi pedaging sebanyak 4 ekor yang telah dijual seharga Rp. 4.000.000 - Rp. 4.250.000, sehingga pendapatan yang diperoleh Rp. 17.000.000. Usaha telah dilanjutkan dengan memasukan bibit babi yang baru sebanyak 8 ekor. Selain itu, keberhasilan juga diperoleh dari kegiatan bercocok tanam jagung hibrida dengan produksi jagung yang dipanen $65,5 \mathrm{~kg} / 600 \mathrm{~m}^{2}$. Kegiatan $\mathrm{IbM}$ ini berhasil meningkatkan pengetahuan, keterampilan dan pendapatan mitra sehingga meningkatkan kesejahteraan keluarga.
\end{abstract}

Keyword-Babi, Pakan, Kandang, Budidaya Jagung

\section{PENDAHULUAN}

Panti asuhan merupakan suatu lembaga yang sangat populer untuk membentuk perkembangan anak-anak yang tidak memiliki keluarga ataupun yang tidak tinggal bersama dengan keluarga karena masalah sosial. Anakanak panti asuhan didampingi oleh pendamping yang menggantikan peran orang tua dalam mengasuh, menjaga, memberikan bimbingan serta pendidikan dan keterampilan. Lembaga sosial ini bila dikelola secara tepat maka akan mempunyai andil besar mencegah terjadinya pengangguran dan pada akhirnya dapat membantu pemerintah mengurangi kemiskinan.

Panti Asuhan Sonaf Maneka merupakan salah satu panti asuhan di Kota Kupang yang didirikan tahun 1980. Visi panti asuhan ini adalah 
menjadi panti asuhan yang unggul dalam pemeliharaan dan pendampingan anak penyandang masalah sosial, dengan salah satu misi yakni mengoptimalkan keterampilan dan kualitas pengelolaan potensi diri penerima manfaat di dalam panti maupun sumber daya di sekitarnya.

Panti asuhan dibagi dalam 2 kelompok besar berdasarkan jenis kelamin agar mempermudah pengelolaannya. Kelompok Sonaf terdiri atas anak laki-laki, dan Kelompok Maneka terdiri atas anak perempuan. Jumlah penghuni panti tahun 2016 berjumlah 125 orang anak yang terdiri atas 69 orang laki-laki dan 56 orang perempuan.

Pendidikan anak-anak panti asuhan juga sering menimbulkan permasalahan dan juga kebutuhan hidup setiap hari selain merupakan sumbangan masyarakat, mereka juga berupaya dengan keterbatasan kemampuan dan keterampilan yang dimiliki mengusahakan beberapa jenis kegiatan diantaranya usaha perbengkelan otomotif, pembuatan batako, bertanam sayuran yang hasilnya untuk dikonsumsi. Sumber daya yang dimliki antara lain lahan 10 20 are, sumber air berupa sumur bor, air pdam, serta memiliki pacul dan parang.

Kelompok Sonaf mengelola usaha perbengkelan otomotif (tambal ban dan servis serta reparasi kendaraan dan pencetakan batako yang merupakan binaan dari Kementrian Sosial Kota Kupang. Sedangkan kegiatan beternak babi juga baru mulai dilakukan tahun 2015 dalam skala kecil. Beternak babi masih dilakukan dalam perkandangan sederhana dan kurang sehat. Potensi produksi babi lokal lebih rendah bila dibandingkan babi unggul, seperti bibit babi unggul Bali dan babi banpres. Kondisi fisik babi yang telah berumur 3,5 bulan sangat kecil dan kurus bila dibandingkan dengan babi unggul.

Ternak babi dipelihara dalam sebuah kandang sederhana yang terbuat dari kayu. Limbah ternak seperti kotoran padat dan cair (urine) terbuang begitu saja sehingga menimbulkan pencemaran udara bagi lingkungan sekitarnya. Hal ini sangat mengganggu kesehatan manusia terutama penghuni panti asuhan. Kondisi kandang yang demikian adalah tidak sehat bagi pertumbuhan babi

Ternak babi diberikan makanan atau pakan seadanya tanpa memperhatikan nilai gizi dalam pakan. Hal ini berdampak terhadap pertumbuhan ternak babi, sehingga babi kelihatan kurus dan tidak sehat.

Kegiatan bercocok tanam biasa dilakukan oleh Kelompok Maneka (mitra 2) setelah pulang sekolah. Kegiatan bercocok tanam hanya dilakukan dalam lahan yang sempit yakni $100 \mathrm{~m}^{2}$ dan tak beraturan penempatannya, sedangkan sisa lahan belum digunakan dan hanya ditumbuhi oleh rumput, semak belukar, dan pohon gamal (gambar 1).

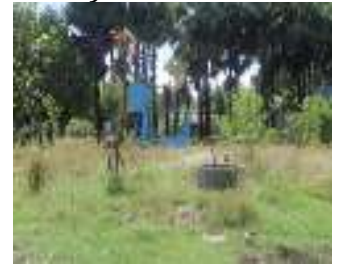

Gambar 1. Kondisi Kebun Mitra

Dalam membudidayakan tanaman tersebut mereka tidak memiliki pengetahuan dan keterampilan. Bercocok tanam dilakukan secara sederhana/tradisional sehingga sering mengalami gagal panen, hasil panen rendah, dan tanaman mati karena terserang hama dan penyakit. Mitra juga belum memiliki kemampuan dan keterampilan yang baik dalam budidaya jagung, seperti lahan tidak diolah, tidak dilakukan pemupukan yang berimbang dan pengendalian organisme pengganggu tanaman (hama, penyakit, dan gulma).

Dalam mengelola usaha masingmasing, kedua mitra tersebut belum mampu merancang manajemen usaha dan pembukuan serta analisis kelayakan usaha yang baik dan benar. 


\begin{abstract}
Menurut pengelola panti asuhan, mereka ingin memberikan keterampilan dan memperluas skala usaha beternak babi pedaging dan mengoptimalkan lahan yang ada dengan budidaya tanaman secara benar, akan tetapi hal tersebut belum dapat terlaksana karena tidak memiliki keahlian, keterampilan dan modal usaha.

Oleh karena itu, perlu dilakukan kegiatan pelatihan keterampilan kepada para penghuni panti asuhan
\end{abstract}

\section{Permasalahan Mitra}

Mitra belum memliki pengetahuan dan keterampilan serta manajemen yang benar dan tepat dalam beternak babi pedaging, meramu pakan babi serta budidaya jagung, padahal potensi sumber daya manusia dan sumber daya lainnya sangat mendukung pengembangan usaha tersebut. Manajemen dan kelayakan usaha juga belum terorganisir secara baik dan benar. Pengetahuan mitra tentang manajemen perencanaan, produksi, pengawasan, dan evaluasi terhadap suatu sistem usaha masih rendah dan belum terorganisir secara baik dan benar.

\section{METODE PELAKSANAAN}

Kegiatan pengabdian ini dilakukan selama tahun 2017 pada mitra Sonaf dan Maneka menggunakan metode metode ceramah (preaching method), diskusi (discussion method), praktik/percobaan (experimental method), dan pendampingan, monitoring dan evaluasi pelaksanaan kegiatan

\section{HASIL DAN LUARAN YANG DICAPAI}

Sebelum pelaksanaan kegiatan dimulai, maka terlebihdahulu tim pelaksana melakukan sosialisasi dengan mitra terkait jenis kegiatan, jadwal pelaksanaan, serta bentuk partisipasi mitra.

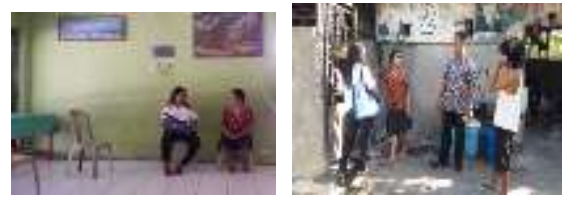

Gambar 2. Sosialisasi Kegiatan IbM

\section{Penyuluhan}

Penyuluhan

dilakukan

dilakukan sebanyak 3 kali yakni :

a. Penyuluhan tentang budidaya jagung hibrida. Materi ini difasilitasi oleh Ir. Mochammad Hasan, MP dan Yosefina Lewar, SP.,MP.

b. Penyuluhan tentang beternak babi pedaging serta teknik meramu pakan babi. Materi ini difasilitasi oleh Ir. Blasius Gharu, MSi dan Yosefina Lewar, SP.,MP, serta nara sumber Radempta Wea, SPt.,MP.

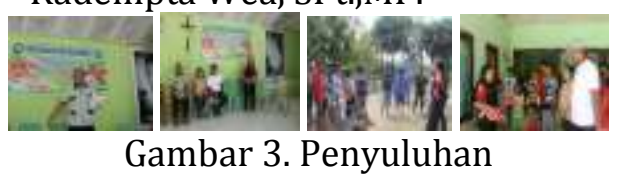

Peserta sangat aktif mendengarkan dan berdiskusi terkait materi yang disampaikan. Berdasarkan hasil evaluasi secara lisan, maka dapat disimpulkan bahwa rata-rata tingkat pengetahuan mitra atas materi IbM cukup baik. Hal ini dikarenakan mitra telah mempunyai pengalaman berkebun dan beternak. Materi tentang meramu pakan babi merupakan pengetahuan baru bagi mitra, sehingga materi ini sangat direspon oleh mitra untuk segera ditindaklanjuti dengan praktek lapangan. Aspek manajemen yang disampaikan kepada mitra adalah manajemen budidaya tanaman dan manajemen beternak babi pedaging. Selain itu juga mitra diajarkan tentang manajemen usaha melalui pelatihan pembukuan usaha secara sederhana.

\section{Pelatihan dan Demplot}

Kegiatan pelatihan dan demonstrasi plot dilakukan secara langsung oleh tim pelaksana yang dibantu oleh teknisi dan mahasiswa.

$\begin{array}{lcc}\text { a. Pembuatan } & \text { Kandang } & \text { Babi dan } \\ \text { Beternak } & \text { Babi } & \text { Pedaging }\end{array}$ 
Pembuatan kadang babi permanen diawali dengan berdiskusi tentang letak dan desain kandang babi. Desain kandang babi dibuat oleh tim pelaksana dan mendapat masukan dari mitra. Rancangan awal kandang babi oleh tim pelaksana berukuran $4 \mathrm{~m} \times 2 \mathrm{~m} \times 2 \mathrm{~m}$ (p $\mathrm{x} \mathrm{l} \times \mathrm{t}$ ), akan tetapi mitra telah memiliki bangunan atau rumah yang dikhususkan untuk kandang ternak. Oleh karena itu disepakati bersama untuk membuat petakan berukuran $3 \mathrm{~m}$ $\mathrm{x} 2 \mathrm{~m}$ dalam bangunan tersebut sebanyak 2 buah untuk beternak babi sebanyak 4 ekor.

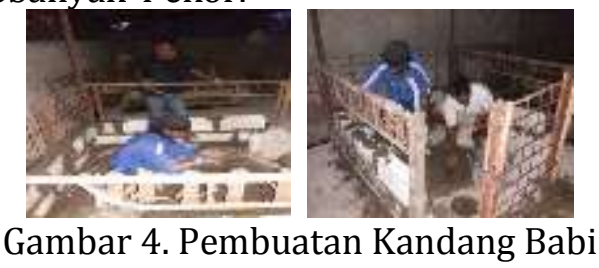

Bibit babi yang digunakan adalah babi Landrace diperoleh dari peternak pembibitan babi yang telah berumur 8 minggu.

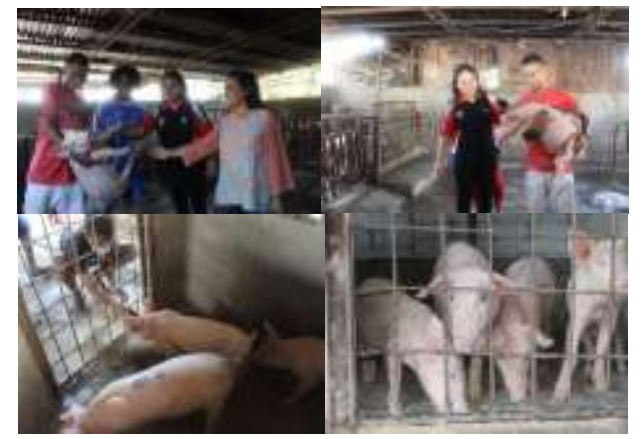

Gambar 6. Kegiatan Beternak Babi

Ternak babi dijual saat babi telah berumur $\pm 6-7$ bulan seharga Rp. 4.000 .000 /ekor (2 ekor babi) dan Rp, 4.500 .000 ( 2 ekor babi) sehingga dari 4 ekor babi tersebut diperoleh penerimaan sebesar Rp. 17.000.000. Mitra kemudian membeli bibit babi sebanyak 8 ekor dan dilanjutkan pemeliharaan dengan memanfaatkan jagung yang telah dipanen sebagai bahan baku pembuatan pakan. Sehingga apabila dipelihara dan siap dijual maka akan diperoleh pemasukan rata-rata
Rp. 34.000.000, jika harga jual babi Rp. 4.250.000/ekor.

b. Membuat Formulasi Pakan Babi Pakan babi terdiri atas 2 yaitu pakan komplit yang dibeli di toko penyedia pakan dan pakan yang diramu sendiri. Pakan komplit ini diberikan ke babi untuk menghindari stres sebelum diberikan pakan ramuan sendiri. Pakan komplit langsung diberikan ke bibit babi. Jadwal pemberian dosis pakan telah dirancang oleh tim pelaksana sehingga mitra melakukannya sesuai petunjuk yang telah dibuat. Pakan yang diramu sendiri merupakan campuran dari tepung jagung, dedak gandum, konsentrat, dan mineral pig mix dengan formulasi yang telah dirancang oleh tim pelaksana dan nara sumber.

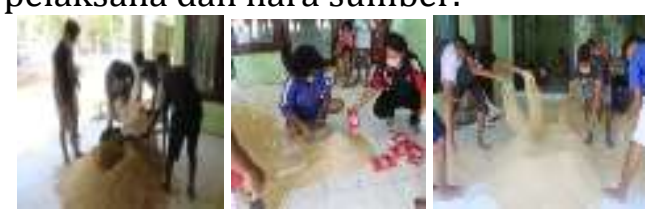

Gambar 6. Pembuatan Pakan Babi

c. Budidaya Jagung

Kegiatan budidaya jagung hibrida berbasis organik dilakukan di lahan milik mitra seluas 6 are. Budidaya dilakukan secara konvensional di lahan. Tahapan kegiatan budidaya tanaman jagung berbasis organik yakni pembersihan lahan, pengolahan tanah, pembentukan bedengan penanaman, pemupukan dasar, penanaman, penyulaman, pengairan, dan pemupukan susulan. Rangkaian kegiatan seperti terlihat pada gambar 7 . 


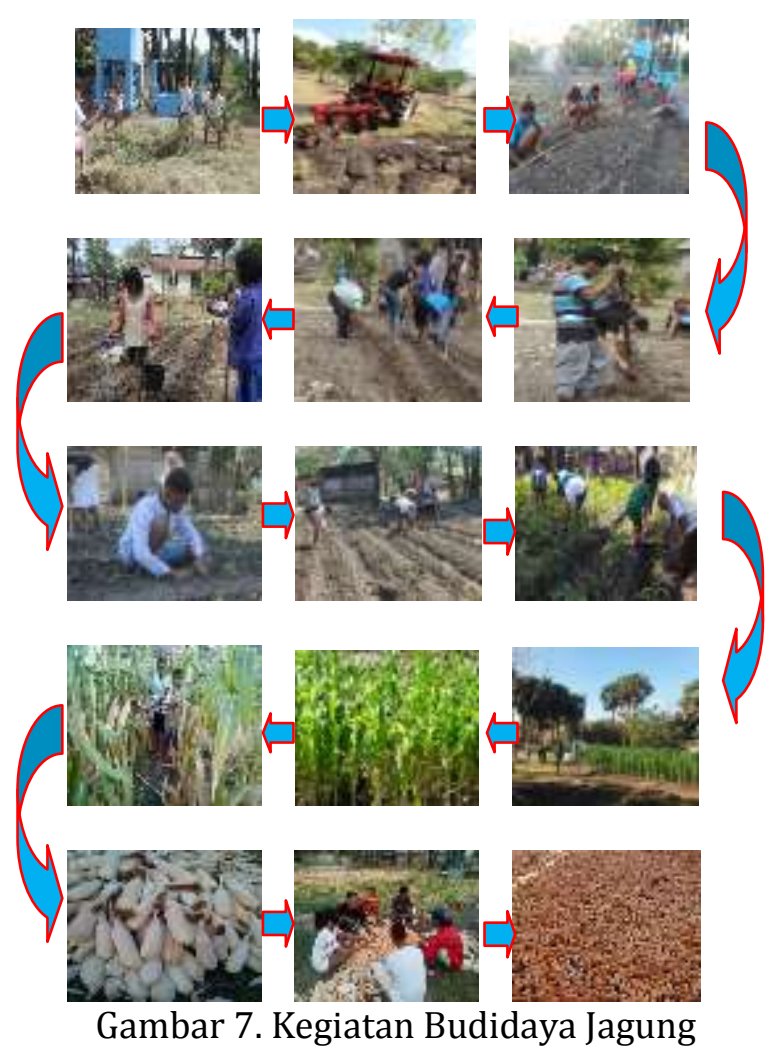

Kegiatan pembersihan lahan atau land clearing dilakukan dengan membersihkan lahan dari tumbuhan pengganggu atau gulma. Setelah itu dilanjutkan dengan pengolahan tanah menggunaka traktor yang dioperasikan oleh petugas. Lahan diolah secara maksimum sebanyak 2 kali yakni pertama pembalikan tanah dan kedua penghancuran tanah sampai siap dibentuk bedeng/petakan.

Setelah lahan diolah maka dilanjutkan dengan pembentukan bedeng/petakan. Bedeng dibentuk dengan panjang bedeng bervariasi tergantung panjang lahan, yakni $10 \mathrm{~m}, 15 \mathrm{~m}$ dan $20 \mathrm{~m}$. Sedangkan lebar bedeng $1 \mathrm{~m}$, tinggi bedeng $20-25 \mathrm{~cm}$ dan jarak antar bedeng $30 \mathrm{~cm}$. Setelah itu diberikan pupuk dasar berupa pupuk kandang sapi dengan dosis $3 \mathrm{~kg} / \mathrm{m}^{2}$. Pupuk kandang ditabur merata di permukaan bedeng kemudian dicampur dengan tanah yang ada di permukaan bedeng. Benih jagung hibrida Varietas Pertiwi ditanam dengan jarak tanam $75 \mathrm{~cm}$ x 20 $\mathrm{cm}$ dengan jumlah benih per lubang 2 butir benih serta kedalaman lubang tanam $2 \mathrm{~cm}$. Setelah benih dimasukan kedalam lubang tanam maka kedalam lubang tersebut dimasukan pestisida Furadan 3G dengan dosis 2 g/lubang, kemudian lubang ditutup dengan tanah. Bedeng penanaman yang ditanami jagung sebanyak 25 bedeng.

Pengairan menggunakan air bersumber dari air PDAM dan sumur bor. Pengairan dilakukan pada pagi dan sore hari. Dalam melakukan kegiatan pengairan dibagi tugas pengairan per bedeng/petak sebanyak 2 orang.

Kegiatan penyulaman dilakukan seminggu setelah penanaman. Penyulaman menggunakan bibit yang telah ditanam dalam petakan kecil saat penanaman. Persentase populasi tanaman yang disulam yakni $5 \%$. Setelah disulam pertumbuhan tanaman jagung normal.

Pemupukan susulan dilakukan 2 kali yaitu saat tanaman berumur 1 minggu setelah tanam dan umur tanaman 3 minggu setelah tanam. Pemupukan susulan menggunakan pupuk kimia NPK dan Urea dengan dosis $100 \mathrm{~kg}$ NPK/ha dan $300 \mathrm{~kg}$ Urea/ha. Pupuk diberikan dengan dua cara yakni pemupukan susulan pertama dengan cara larikan sedangkan pemupukan susulan kedua dengan cara tugal per tanaman. Pupuk diberikan dalam lubang pupuk kemudian ditutup menggunakan tanah di bedeng. Pada saat pemupukan dilakukan pengendalian gulma dan pendangiran atau penggemburan tanah di atas bedeng.

Pengendalian hama dilakukan secara fisik dan mekanik. Hama yang menyerang tanaman jagung seperti belalang dan ayam akan tetapi tidak merugikan tanaman. Pengendalian hanya dilakukan secara fisik yaitu menangkap dan mengusir hama. Sedangkan serangan penyakit tidak banyak ditemui di pertanaman jagung. Jagung Varietas Pertiwi yang ditanam mitra adalah jagung yang tahan terhadap penyakit bulai, hawar daun dan karat daun. Selain itu, mitra juga melakukan pengendalian gulma secara 
mekanik menggunakan tajak atau tofa. Tim pelaksana menyarankan kepada mitra untuk tidak melakukan pengendalian secara kimiawi untuk menghindari polusi karena banyak anak-anak di sekitar lingkungan pertanaman jagung.

Kegiatan pemangkasan dilakukan dengan cara memangkas daun-daun jagung bagian bawah yang telah tua dan kering, hal ini dilakukan untuk memfokuskan nutrisi untuk pertumbuhan dan pembesaran buah jagung.

Varietas jagung yang ditanam mitra adalah Varietas Pertiwi. Varietas ini dipanen kering pada umur 103 hari setelah tanam. Di lapangan mitra memanen jagung kering umur 106 hari setelah tanam. Potensi produksi jagung Varietas Pertiwi adalah 13,73 ton/ha dengan rata-rata produksi 9,40 ton/ha. Produksi jagung yang dihasilkan oleh mitra pada lahan seluas $600 \mathrm{~m}^{2}$ adalah 65,5 kg jagung pipil kering dengan kondisi jagung sangat baik dan butir jagung besar. Jagung dipanen secara gotong royong oleh mitra kemudian dikupas dan dijemur, setelah itu dipipil dan disimpan sebagai bahan baku pembuatan pakan babi.

\section{Faktor Pendukung dan Penghambat}

Faktor pendukung terlaksananya kegiatan IbM di lapangan adalah :

1. Partisipasi mitra

Mitra berpartisipasi aktif dalam setiap tahapan kegiatan IbM. Mitra dengan kemampuannya dapat mengelola semua kegiatan IbM dengan baik sampai dipanen atau diperoleh hasil dan pemasaran bahkan kegiatan dilakukan secara kontinyu.

2. Sarana pendukung kegiatan

Fasilitas yang dihibahkan kepada mitra seperti kandang babi dan babi serta peralatan budidaya sangat membantu mitra dalam mengembangkan kegiatan secara kontinyu.

3. Pasar

Pasaran ternak babi pedaging sangat luas. Ternak babi yang dihibahkan pada awal kegiatan sebanyak 4 ekor telah dijual dan digunakan untuk membeli bibit babi yang baru.

Faktor-faktor yang menjadi kendala yang dihadapi selama pelaksanaan kegiatan IbM terutama kegiatan budidaya jagung karena kendala air penyiraman. Karena air yang tersedia selain untuk menyiram tanaman, terutama digunakan untuk mandi, minum dan mencuci, apalagi jumlah penghuni panti asuhan yang banyak (128 anak). Akan tetapi tidak menjadi penghambat terlaksananya kegiatan IbM, karena ketersediaan air bagi tanaman terpenuhi dengan melakukan penyiraman secukupnya.

\section{KESIMPULAN}

1. Kegiatan IbM Sonaf dan Maneka telah terlaksana dengan baik dan berhasil, hal ini dikarenakan partisipasi aktif dan semangat kerja yang tinggi dari mitra.

2. Kegiatan IbM mampu menyelesaikan permasalahan mitra, khususnya dalam hal pengetahuan dan keterampilan beternak babi pedaging dan meramu pakan babi dan budidaya jagung serta merencanakan suatu usaha dan pembukuan usaha secara sederhana

3. Kegiatan IbM ini sangat bermanfaat bagi mitra, selain melatih keterampilan mitra juga sebagai sumber pendapatan dan kesejahteraan mitra.

\section{UCAPAN TERIMA KASIH}

Terimakasih kepada Direktorat Riset dan Pengabdian Masyarakat (DRPM) Dikti, Kementrian Riset, Teknologi dan Pendidikan Tinggi yang telah mendanai kegiatan IbM Sonaf dan Maneka tahun 2017.

\section{DAFTAR PUSTAKA}

Anonim. 2008. Teknologi Budidaya Jagung. Balai Besar Pengkajian dan Pengembangan Teknologi Pertanian, Badan Penelitian dan Pengembangan Pertanian. 
Anonim, 2014. Benih Jagung Pertiwi Tahan Bulai. Benihnya Petani Indonesia. www.benihpertiwi.co.id.

Nugroho E dan Wheindrata. 1990. Beternak Babi. Eka Offset. Semarang.

Rukmana R dan Yuyun Yuniarsih, 1996. Jagung - Budidaya dan Pascapanen. Kanisius. Yogyakarta.

Sihombing, D. T. H, 1998. Ilmu Ternak Babi. Gadjah Mada Press. Yogyakarta.
Sutanto, R. 2002b. Penerapan Pertanian Organik, Pemasyarakatan dan Pengembangannya. Kanisius. Yogyakarta.

Warisno. 1998. Jagung Hibrida. Seri Budi Daya. Kanisius. Yogyakarta.

Wheindrata. 2014. Cara Mudah Untung Besar Dari Beternak Babi. Andi Publisher. Yogyakarta. 